DOI: 10.34015/2523-4552.2020.3.11

УДК 343.131(477)

Сіроткіна М., кандидат юридичних наук, здобувач кафедри кримінального процесу та криміналістики Інституту права Київського національного університету імені Тараса Шевченка

ORCID: 0000-0001-7897-409X

\title{
ЗАСТОСУВАННЯ ПРОЦЕДУРИ МЕДІАЦІЇ У КРИМІНАЛЬНОМУ ПРОЦЕСІ АВСТРІЇ, ФРН ТА ШВЕЙЦАРІЇ
}

У статті проаналізовано кримінальне процесуальне законодавство та нормативно-правові акти, якими регламентується врегулювання кримінально-правових спорів за допомогою медіативних процедур у Федеративній Республіці Німеччина, Австрії та Швейцарії. Зроблено висновок, що в різних країнах такі примирювальні процеси відбуваються по різному, в більшості в позитивному аспекті. Хоча, наприклад, така успішна й економічно розвинута держава як Швейцарія визнає медіацію недоцільною та невиправданою в економічному плані. У ФРН та Австрії примирювальні процедури, навпаки, застосовуються ефективно ще з кінця минулого століття.

Ключові слова: Австрія; медіація; примирення; ФРН; Швейцарія.

В статье проанализированы уголовное процессуальное законодательство и нормативно-правовые акты, которыми регламентируется урегулирование уголовно-правовых споров с помощью медиативных процедур в Федеративной Республике Германия, Австрии и Швейцарии. Сделан вывод, что в разных странах такие примирительные процессы происходят по-разному, в большинстве стран - в положительном аспекте. Хотя, примером, такая успешная экономически развитая страна как Швейцария признает медиацию нецелесообразной и неоправданной в экономическом плане. В ФРГ и Австрии примирительные процедуры, наоборот, применяются эффективно еще с конца прошлого века, когда еще не было принято соответствующих нормативных актов по урегулированию процедуры медиации.

Ключевые слова: Австрия; медиация; примирение; ФРГ; Швейцария.

Постановка проблеми. Інститут медіації останнім часом $є$ доволі актуальною темою для обговорення в українських правових колах. Технології альтернативного врегулювання спорів усе частіше опиняються в центрі уваги як науковців, так i практиків. Незважаючи на те, що
Україна перебуває лише на етапі формування вітчизняної моделі відновного правосуддя, ідеї впровадження цього інституту в систему законодавства підтримує широке коло спеціалістів. Такий інтерес відповідає прагненням України інтегруватися до Європейського Союзу й 
адаптувати своє законодавство до європейського [1, с. 3].

У чому ж секрет такого стрімкого поширення ідей відновного правосуддя i, зокрема, застосування медіації, у всьому світі? Медіація має дуже довгу історію. Вона існувала ще тоді, коли не існувало тюрем і у деяких спільнотах прийнята як єдиний засіб розв'язання конфліктів між сторонами. На даний час програми примирення успішно діють в Норвегії, Фінляндії, Великобританії, Австрії, Німеччині, Франції та закріплені на рівні національного законодавства. Так, в одному із регіонів Великобританії на медіацію направляють щорічно близько 1500 справ. За результатами опитування $76 \%$ жертв та $92 \%$ правопорушників були задоволені медіацією. В Шотландії прокурори можуть займатися справою лише тоді, коли медіація вже закінчена. В інших країнах Європи здійснені перші кроки у вигляді пілотних проєктів. Тут можна назвати Данію, Швецію, Нідерланди, Ірландію, Іспанію та Італію. Протягом останніх років активізувався рух за впровадження програм примирення в Східній Європі. Застосування інституту медіації у ФРН, Австрії та Швейцарії має свої особливості, що $є$ цікавим $\mathrm{i}$ для вітчизняних правників, так як в Україні медіація хоч застосовується у кримінальному провадженні, однак на законодавчому рівні не закріплена.

Аналіз останніх досліджень і публікацій. Незважаючи на актуальність, питання щодо застосування процедури медіації у кримінальному провадженні, досвід законодавця інших країн, зокрема ФРН, Австрії та Швейцарії, вивчений досить поверхово. Дослідженню окремих аспектів означеної проблематики присвятили свої наукові праці вітчизняні та зарубіжні вчені Р. Ф. Аракелян, А. В. Біцай, А. С. Василенко, Н. І. Гайдаєнко-Шер, Л. В. Головко, І. Керімі, Є. О. Курта, Л.М.Лобойко, I. В. Паризький, Г. О.Усатий, I. Г. Ясиновський та інші. Однак чимало питань, пов'язаних із медіативними процедурами у зарубіжних країнах залишились малодослідженими.

Постановка завдання. Метою статті $€$ аналіз досвіду застосування правниками Федеративної Республіки Німеччина, Австрії та Швейцарії процедури медіації у кримінальному провадженні.

Виклад основного матеріалу. Основи медіації з'явилися у ФРН із переорієнтуванням із класичної системи призначення покарань на більше врахування інтересів потерпілого. Наслідком прагнень німецьких правників покращити становище потерпілого та забезпечити більш ефективне відшкодування заподіяних йому збитків стало прийняття Закону «Про відшкодування шкоди потерпілим» від 11 травня 1976 року та Закону «Про захист потерпілих» від 18 грудня 1986 року. Із прийняттям останнього було законодавчо закріплено інститут «ТОА» (Täter-Opfer Ausgleich) «досягнення компромісу між винуватою особою та потерпілим» та внесення у зв'язку з цим відповідних змін до Кримінального та Кримінально-процесуального кодексів [2, с. 89-90].

До цього часу ТОА діяв на рівні модельних проєктів зацікавлених у ньому кіл. Вони були спрямовані спочатку на кримінальні справи за 
участю неповнолітніх, а згодом і дорослих осіб. В межах проєктної діяльності у правову систему були інстальовані посередницькі установи, які, за згодою органів юстиції, здійснювали медіаційне провадження у справах про нетяжкі злочини та злочини середньої тяжкості [3, с. 67].

У § 46а КК ФРН було передбачено, що «якщо винуватий прагне дійти компромісу 3 потерпілим, відшкодував заподіяні ним збитки повністю або більшою частиною, або має серйозні наміри зробити це, то суд може покарання пом'якшити або, якщо санкція статті не передбачає покарання у вигляді позбавлення волі більше, як на один рік, або грошовий штраф в розмірі 360 денних ставок*, звільнити від нього повністю» $[4$, с. 26].

У свою чергу відповідно до $\S 155 а$ КПК ФРН прокуратура і суд у кожній стадії провадження повинні перевірити можливість досягнення угоди між обвинуваченим i потерпілим. У разі ії наявності вони повинні цьому сприяти. Без згоди потерпілого угода не може бути укладена [5, с. 198]. Що стосується застосування ТОА у провадженні за участю неповнолітніх осіб (до 18 років) чи молоді (осіб до 21 року), то у § 45 Закону «Про відправлення правосуддя у справах молоді» від 4 серпня 1953 року міститься положення, згідно з яким у порівнянні із санкціями, які може накласти суддя, слід надавати перевагу інституту TOА. Окрім того, згідно §10 цього закону суд може в якості виховного заходу зобов'язати неповнолітнього обвинуваченого намагатися укласти угоду з потерпілим [6].

Як відмічається в німецькій літературі, процедура TOА в законі не врегульована детально, очевидно законодавець переслідував мету дати більше простору для врегулювання конфліктів та досягнення компромісу при їх вирішенні на рівні земель. Так чи інакше прокуратура чи суд не вправі самостійно провести примирення між потерпілим та обвинуваченим, а повинні залучити для цього відповідні органи.

Такими органами для дорослих обвинувачених слугують представники так званої «судової допомоги», соціальна служба юстиції та уповноважені на це інші особи, які вправі виконувати медіаційні функції [3, c. 81-82]. Судову допомогу у вигляді надання суду різного роду інформації здійснюють представники різних, як правило, соціальних служб. Вони не виступають учасниками кримінального провадження, проте можуть бути допитані як свідки [7, c. 131].

Згадані «інші особи» здійснюють свої функції в межах різних ТОАпроєктів та $\epsilon$ підготовленими фаховими медіаторами. У провадженнях за участю неповнолітніх чи молодих людей саме вони виступають посередниками як представники судової допомоги, виконуючи таким чином додаткову функцію, або виключно лише в якості медіаторів. У справах за участю дорослих осіб вони можуть брати участь лише за їх згодою.

* Примітка авт.: відповідно до § 40 КК ФРН грошовий штраф призначається у вигляді денних ставок - суми, яку підсудний отримував або міг би отримати за один день з урахуванням його матеріального стану. В грошах така сума обчислюється в розмірі від 1 до 5 тисяч євро за одну денну ставку. 
Згідно § 2 Закону «Про сприяння посередництву та іншим процедурам позасудового врегулювання конфліктів» від 21 липня 2012 року медіатор повинен забезпечити розуміння сторонами принципів та ходу медіаційного процесу та факт того, що вони добровільно беруть участь у медіації. Посередник однаково зобов'язаний всіма сторонами. Він сприяє спілкуванню між сторонами та забезпечує залучення сторін до медіації належним та справедливим чином. Він може вести окремі переговори зі сторонами зі всіх сторін. Треті сторони можуть бути включені до медіації лише за згодою всіх сторін.

У разі домовленості посередник працює над тим, щоб сторони уклали угоду зі знання фактичної ситуації та зрозуміли ії зміст. Він повинен повідомити сторони, які беруть участь у медіації без консультації спеціалістів, що угоду можуть перевірити зовнішні консультанти, якщо це їм необхідно. За згодою сторін досягнута угода може бути задокументована в остаточній угоді [8].

Наведений § 46 КК ФРН регулює призначення покарання i містить дві можливості для проведення медіації. У першому випадку під час медіації сторони заключають угоду, умовою якої $\epsilon$ відшкодування шкоди і щире каяття правопорушника. Потерпілий може зменшити розмір відшкодування до мінімуму, але вибачення перед потерпілим $\epsilon$ обов'язковою вимогою для правопорушника. У другому випадку правопорушник повинен відшкодувати тільки матеріальну шкоду в повному обсязі і визнати наслідки скоєного, однак ця компенсація повинна бути значною і зроблена внаслідок осо- бистих зусиль правопорушника. Далі суд може врахувати результати медіації під час прийняття рішення та винесення вироку і зменшити покарання підсудному. Дані положення поширюються на всі злочини, вчинені проти особи.

3 урахуванням аналізу відповідних норм КК та КПК ФРН можна дійти висновку, що при застосуванні інституту ТОА та медіації у Німеччині:

- органи кримінального переслідування вправі припинити таке переслідування, якщо публічні інтереси не вимагають його продовження (§§ 153a, 153b КПК ФРН);

- у випадку його продовження від призначення покарання може відмовитися суд або хоча б його пом'якшити (§§ 46, 46а КПК ФРН);

- спонукання до досягнення компромісу може бути ініційовано судом відносно неповнолітніх в якості виховного заходу (§10 абзац 1 п.7 Закону «Про відправлення правосуддя у справах молоді»);

- право на досягнення компромісу діє і під час відбування покарання засудженим чи при застосуванні санкції, не пов'язаної з позбавленням волі.

3 наведеного можна зробити висновок, що така система $є$ досить гнучкою та ефективною, оскільки діє в усіх стадіях кримінального процесу; рішення про застосування «TOA» може бути прийнято відповідно не лише судом, а й органами кримінального переслідування, що дає можливість не затягувати процес; спрямована на відшкодування заподіяної шкоди потерпілому 3 боку обвинуваченого чи засудженого, а не з боку держави; ефективно слугує ресоціалізації злочинця, спо- 
нукає його до розкаяння та недопущення ним скоєння нових злочинів [9, c. 158].

В Австрії посередництво між потерпілим та злочинцем стало альтернативою у кримінальному провадженні у 1985 році в межах так званої «диверсії» (Diversion) - відмови від кримінального переслідування за наявності для цього передумов (сплата грошового внеску, виконання суспільних робіт, проходження випробувального терміну) [7, с. 219].

Аналіз досвіду запровадження такої можливості засвідчив, що в даному випадку йшлося значною мірою про правопорушення, що грунтуються на конфлікті в соціальній сфері (у подружніх стосунках, у сім'ї, у відносинах із сусідами, на роботі). Незважаючи на те, що покарання та засудження винного $\epsilon$ пріоритетним в офіційному (публічному) судовому процесі, позасудове врегулювання правопорушень стосується керування конфліктом та відшкодування заподіяної злочином шкоди. Переговори про справедливе вирішення конфлікту за допомогою посередника та розробка стратегій майбутньої поведінки сторін $є$ основою медіаційної процедури [10].

Сторони не зобов'язуються до врегулювання конфлікту, однак їм пропонується можливість здійснення медіації. Тому, власне, процесу медіації передує передмедіативний етап 3 метою надання їм інформації про правову ситуацію та хід провадження, вивчення інтересів i намірів потерпілого та обвинуваченого і забезпечення їх подальшої комунікації. У ході цього процесу медіатори часто спочатку зустрічаються індивідуально 3 кожною зі сторін та збирають їх разом, як тіль- ки будуть виконані відповідні умови. При проведенні медіації існує безліч різних методів компенсації шкоди та врегулювання конфлікту.

Повноваження ініціювання медіації покладається на прокуратуру, проте судді також можуть ініціювати врегулювання конфлікту до закінчення основного слухання. По відношенню до неповнолітніх медіація можлива у разі вчиненні злочину, за який передбачено покарання у вигляді позбавлення волі на строк до п'яти років (що відповідає 10-ти рокам позбавлення волі у провадженні щодо дорослих осіб). Якщо медіація відбувається на стадії судового розгляду, то суд вправі перейти і ці встановлені КК верхні межі.

У 1995 році в Австрії була заснована Федеральна асоціація 3 медіації (ӦВМ). Налічуючи близько 2400 кваліфікованих членів, вона $\epsilon$ найбільшою спеціалізованою посередницькою організацією в Європейському Союзі. Посередництво в процесі врегулювання спору у кримінальному провадженні у їі рамках здійснюється по всій Австрії через посередницькі асоціації Neustart [11].

Відповідно до § 204 КПК Австрії «прокуратура може відмовитися від кримінального переслідування за вчинення кримінального правопорушення, якщо воно безпосередньо зачіпає інтереси конкретної особи, обвинувачений визнає свою вину та готовий її загладити, зокрема шляхом відшкодування шкоди, заподіяної діянням, або іншим чином сприяє відшкодуванню наслідків діяння, та за потреби взяти на себе зобов'язання, які свідчать про його готовність утримуватися надалі від поведінки, яка призвела до вчинення злочину. 
Потерпілий та його представник беруть участь у намаганнях відшкодування шкоди за їх бажанням. Врегулювання такого конфлікту залежить від згоди потерпілого та 3 обов'язковим врахуванням його законних інтересів.

Прокурор може вимагати від регулятора конфлікту повідомити потерпілого та обвинуваченого та їх представників про можливість укладення угоди, а також особисто підтримує їх зусилля щодо компенсації завданої шкоди. У цьому випадку прокурор тимчасово відмовляється від переслідування.

Регулятор конфлікту повинен повідомити прокуратуру про медіаційну угоду та перевірити іiі виконання. Він повинен скласти підсумковий звіт про те, що обвинувачений виконав свої зобов'язання хоча б настільки, наскільки, зважаючи на іншу його поведінку, можна припустити, що він буде продовжувати виконувати домовленості, або про те, що вже не можна очікувати, що врегулювання буде досягнуто» [12, с. 253-254].

Істотними елементами медіації австрійські правники вважають:

- добровільну участь конфліктуючих сторін у позасудовому процесі;

- нейтральність та неупередженість посередника (медіатора);

- намагання домогтися швидкого та небюрократичного залагодження конфлікту;

- придатність посередника виступати в ролі «юридичного експерта» [13].

У Швейцарії, навпаки, медіація широко застосовується у цивільних, сімейних трудових та інших спорах, однак не знайшла свого закріплення у кримінальному процесуальному законодавстві цієї держави, хоч певні приватні асоціації, які надають посередницькі послуги, діють в окремих кантонах на рівні пілотних проєктів. Немає у конфедерації також і Закону «Про медіацію».

Так, приватна асоціація в кантоні Цюріх під назвою «Konsens» пропонувала процедуру посередництва у кримінальному провадженні протягом трьох років. Кожен, хто став жертвою злочину або скоїв злочин у кантоні Цюріх, мав альтернативу кримінальному провадженню - якщо умови $\epsilon$ відповідними і якщо всі учасники погоджуються. Посередники успішно здійснювали посередництво майже у всіх випадках, але виникали труднощі 3 фінансуванням. Спеціалісти отримували внески з фонду лотереї, фінансувалися Міністерством юстиції, із церковних пожертв або приватних фондів. Пробне випробування коштувало майже 1 мільйон швейцарських франків і асоціація не змогла продовжувати збирати кошти, незважаючи на успішну роботу [14].

Національна рада (законодавча палата парламенту Швейцарії) виступила проти запровадження медіації у кримінальному процесі, хоч посередництво дало б прокурору можливість сприяти мировому вирішенню конфлікту між потерпілим та злочинцем. Рада кантонів пристала на пропозицію Федеральної ради, яка підтримувала ідею медіації, і хотіла залишити ï на кантонах, щоб запровадити посередництво у кримінальному процесі. Тим часом Федеральна рада також відмовилася від свого плану, так як досвід кантону Цюріх показав, що витрати на посередництво виявилися надто високими. 
Наразі медіація зазвичай можлива лише у провадженнях за участю неповнолітніх. Так, у кантоні Фрібур суддя може запропонувати стороні процедуру посередництва у будьякий час та доручити Управлінню з питань посередництва у справах неповнолітніх або, можливо, присяжному посереднику організацію іiі проведення. Якщо досягнуто згоди, суддя згодом припиняє зупинене кримінальне провадження. Посередництво в справах щодо неповнолітніх $є$ безкоштовним [15].

Висновки. Аналізуючи все вищезазначене, варто зауважити, що аналіз зарубіжного досвіду його запровадження у практику вирішення конфліктів показує, що в різних країнах такі процеси відбуваються по різному, в більшості в позитивному аспекті. Хоча, наприклад, така успішна економічно розвинута держава як Швейцарія визнає медіацію недоцільною та невиправданою в економічному плані. У ФРН та Австрії примирювальні процедури, навпаки, застосовуються ефективно ще 3 кінця минулого століття, коли ще не було прийнято відповідних нормативних актів щодо врегулювання процедури медіації.

\section{Список використаних джерел}

1. Ясиновський І. Г. Імплементація процедури медіації в українське законодавство: теоретико-правовий аналіз : дис. ... канд. юрид. наук : 12.00.01. Київ ; Нац. акад. внутр. справ, 2016. 295 с.

2. Галаган О. І., Савченко В. А. Захист прав і свобод суб'єктів кримінального судочинства в Україні та ФРН : навч. посібник для студ. ВНЗ. Івано-Франківськ : Місто HB, 2011. 206 c.

3. Schroth Klaus. Die Rechte des Opfers im Strafprozess. C.F. Müller Verlag. Heidelberg, 2005. $338 \mathrm{~s}$.

4. $\quad$ Strafgesetzbuch. 40 Aufl. Verlag C.H. Beck. München. Texte im dtv, 2005. 309 s.

5. Савченко В. А., Соловій Я. І., Фелик В. І., Юрчишин В. Д. Основи кримінального процесу Федеративної Республіки Німеччина : навч. посібник. Харків : Право, 2017. 372 c.

6. Jugendgerichtsgesetz (JGG) von 4 August 1953 (BGBl. 1 S. 751). URL: https://www.gesetze-im-internet.de/jgg/_10.html (дата звернення: 11.09.2020).

7. Сучасний кримінальний процес країн Європи : монографія / [В.В. Луцик, В.А. Савченко, B.I. Самарін та ін.] ; за ред. В.В. Луцика, В.І. Самаріна. Харків : Право, 2018. $792 \mathrm{c}$.

8. Gesetz zur Förderung der Mediation und anderer Verfahren der außergerichtlichen Konfliktbeilegung vom 21.07.2012. URL: https://dejure. org/BGBl/2012/BGBl._I_S._1577 (дата звернення: 11.09.2020).

9. Савченко В.А. Процесуальне становище потерпілого у кримінальному судочинстві Федеративної Республіки Німеччина. Південноукраїнський правничий часоnuc. № 3. 2006. С. 158.

10. Mediation im Strafrecht. URL : https://www.mediation.at/contents/3859/ mediation-im-strafrecht (дата звернення: 11.09.2020).

11. Recht Easy. Tatausgleich. URL : https://www.rechteasy.at/wiki/ tatausgleich (дата звернення: 11.09.2020)

12. Strafprozessordnung. StPO 1975. Herausgeg. von Helene Bachner-Foregger. Wien ; Manzsche Verlags- und Universitätsausbildung, 2008. 501 s. 
13. Qerimi Islam. Mediation in Österreich. S. 8. URL : https://www.polizeinewsletter.de/documents/2013_Qerimi_Mediation_in_Osterreich.pdf. (дата звернення: 11.09.2020)

14. Eine Alternative zum Strafverfahren. NZZ. 2019. URL : Neue Zürcher Zeitung.https://www.nzz.ch/ articleDK62A-1.9757?reduced=true (дата звернення: 11.09.2020).

15. Auch weiterhin keine Mediatoren bei Strafprozessen. Pilatus Today. URL : https://www.pilatustoday.ch/diverse-news/-auch-weiterhin-keine-mediatoren-beistrafprozessen-136906178 (дата звернення: 18.09.2020).

\section{References}

Yasinovskiy, I. G. (2016). Implementatsiya protsedury mediatsii v ukrainskoye zakonodatelstvo: teoretiko-pravovoy analiz : dis. ... kand. yurid. nauk : 12.00.01. Kiyev, Nats. akad. vnutr. del [in Ukrainian].

Galagan, A. I., Savchenko, V. A. (2011). Zashchita prav i svobod subyektov ugolovnogo sudoproizvodstva v Ukraine i FRG. Ivano-Frankovsk: Gorod NV [in Ukrainian].

Schroth, Klaus (2005). Die Rechte des Opfers im Strafprozess. C.F. Müller Verlag. Heidelberg.

Savchenko, V. A., Soloviy, Y. I., Felyk, V. I., Yurchyshyn V. D. (2017) Osnovy kryminalnoho protsesu Federatyvnoyi Respubliky Nimechchyna. Kharkiv : Pravo [in Ukrainian].

Lutsyka, V. V., Samarina, V. I. (red.). (2018). Suchasnyy kryminalnyy protses krayin Yevropy. Kharkiv: Pravo [in Ukrainian].

Savchenko, V. A. (2006). Protsesualne stanovyshche poterpiloho u kryminalnomu sudochynstvi Federatyvnoyi Respubliky Nimechchyna. Pivdennoukrayinskyy pravnychyy chasopys, 3, 158 [in Ukrainian].

M. Sirotkina, PhD in Law, Applicant of the Department of Criminal Procedure and Criminalistics of the Institute of Law Taras Shevchenko National University of Kyiv

ORCID: 0000-0001-7897-409X

\section{Application of the mediation procedure in the criminal process of Austria, Germany and Switzerland}

The article analyzes the criminal procedure legislation and regulations governing the settlement of criminal disputes through mediation procedures in the Federal Republic of Germany, Austria and Switzerland.

It is stated that mediation has a very long history. It existed even when prisons did not exist and was accepted in some communities as the only means of resolving conflicts between the parties. At present, reconciliation programs are successfully operating in Norway, Finland, the United Kingdom, Austria, Germany, and France and are enshrined in national law.

In Germany, the institute of mediation was established with the adoption of the Law "On Compensation to Victims" of May 11, 1976 and the Law "On Protection of Victims" of December 18, 1986. With the adoption of the latter, the institute "Täter-Opfer Ausgleich" was established by law - "reaching a compromise between the guilty person and the victim" and making appropriate amendments to the Crim- 
inal and Criminal Procedure Codes. the mediator must ensure that the parties understand the principles and course of the mediation process and the fact that they voluntarily participate in the mediation. The mediator is equally obligated by all parties. It facilitates communication between the parties and ensures that the parties are involved in mediation in a proper and fair manner. He can negotiate separately with parties from all sides. Third parties may be involved in mediation only with the consent of all parties.

Austrian lawyers consider the voluntary participation of the conflicting parties in the out-of-court process to be essential elements of mediation; neutrality and impartiality of the mediator; attempts to resolve the conflict quickly and unbureaucratically; the suitability of the mediator to act as a "legal expert".

In Switzerland, on the other hand, mediation is widely used in civil, family, labor and other disputes, but is not enshrined in the country's criminal procedure law, although some private mediation associations operate in some cantons at pilot level. The confederation also does not have a Law on Mediation.

It is concluded that in different countries such reconciliation processes take place in different ways, mostly in a positive aspect. Although, for example, such a successful economically developed country as Switzerland recognizes mediation as inexpedient and economically unjustified. In Germany and Austria, on the other hand, conciliation procedures have been used effectively since the end of the last century, when the relevant regulations governing the mediation procedure had not yet been adopted.

Keywords: Austria; mediation; reconciliation; Germany; Switzerland. 